\title{
Field choice of autumn staging and wintering geese in south- western Sweden 1977/78-2011/12
}

\author{
Fältval hos höstrastande och övervintrande gäss i sydvästra Sverige 1977/1978- \\ $2011 / 2012$
}

\author{
LEIF NILSSON \& HAKON KAMPE-PERSSON
}

Field choice was recorded during counts of geese in South-west Scania, South Sweden in autumn (October and November) and in winter (January), 1977/1978$2011 / 2012$. Sugar beet spill was the most important field type in autumn and during the last ten years also in winter. Bean Geese Anser fabalis used this food source when the study started while Canada Geese Branta canadensis, Greylag Geese Anser anser, White-fronted Geese Anser albifrons and Barnacle Geese Branta leucopsis followed during the years 1987-2001. Potatoes were mainly used when fields with sugar beet spill were unavailable. Cereal stubbles were mainly used in autumn and to a quite low extent. Winter cereals were heavily used by most species in both autumn and winter during the first 15 years but less so thereafter. Grasslands were mainly used in winter, to a large extent by White-fronted Geese and to a quite high extent by Bean Geese and Barnacle Geese. The total use of oilseed rape was low, mainly by Canada Geese that utilised fields with no-till when the ground was snowcovered.

Leif Nilsson, Department of Biology, Lund University, Ecology Building, SE-22362 Lund, Sweden. Email: leif. nilsson@biol.lu.se

Hakon Kampe-Persson, Pulmañi, Glūdas pagasts, Jelgavas novads, LV-3040, Latvia.Email: kampepersson@ hotmail.com.

Received 28 February 2013, Accepted 25 April 2013, Editor: J. Waldenström

\section{Introduction}

During recent decades most goose populations in Sweden and other countries in North-west Europe have increased very markedly (Fox et al. 2010, Nilsson 2013 and references therein). At the same time, there have been marked changes in the distribution patterns of different goose populations, partly reflecting changes in migration patterns (see Nilsson 2013 for further references). These changes have been largely related to changes in agriculture, but also to changes in hunting practices (Nilsson \& Persson 1984, 1991, 2000, Nilsson 2000, 2013).

The habit of geese to feed in farmland has since long caused conflicts with farmers. Problems with Egyptian Geese Alopochen aegypticus are mentioned in a text written already 3000 years ago (Houlihan 1986). However, it was during the agricultural revolution in the 18th and 19th centuries that the geese turned to farmland in increasing numbers, as vegetation more nutritious than wild grasses was developed and grown intensively. To alleviate crop damage farmers started to scare the birds away from their fields. In north-central Spain, the villages employed boys, so called ganseros, to keep the geese from the autumn-sown crops (Madoz 1849). Several studies, both in Sweden and abroad, have tried to prove and quantify crop damage caused by geese, however, often with inconclusive results (Jönsson 1982, Owen 1990). Different measures to mitigate conflicts between geese and farmers have been adopted, such as scaring, shooting license to prevent crop damage, accommodation fields, management plans, refuges and compensation (Owen 1977, van Roomen \& Madsen 1992, Edberg 2003, Axelsson \& Modin 2006, Oord 2009, Hake et al. 2010). To ascertain which measure to adopt data about the field choice of the geese are needed.

Field choice of staging and wintering geese have been intensively studied in southernmost Sweden from time to time since the late 1950s, making it possible to follow changes in the utilisation of the Swedish farmland by increasing goose populations (Markgren 1963, Mellquist \& Nilsson 1968, Persson 1982, 1989, Nilsson \& Persson 1984, 1991, 1992, 1998, 2000). The field choice and habitat 
selection of staging and wintering geese was studied more extensively in South-west Scania, south Sweden during 1956/57-1958/59 (Markgren 1963) and 1977/1978-1986/1987 (Persson 1982, 1989, Nilsson \& Persson 1984, 1991). However, the world is continuously changing for both man and geese. Climate change can improve the conditions for wintering geese (Nilsson 2013), geese can learn new feeding habits (Kear 1990) while new crops, sorts and varieties and new farming techniques can drastically change the feeding opportunities for the geese. These factors urge for an up-date of our knowledge about field choice of staging and wintering geese.

Since the start of regular goose counts in Sweden in 1977/1978 (Nilsson 2013), the field choice of the staging and wintering geese in South-west Scania have been registered during the counts in October, November and January in most years. In this contribution, the field choice of the geese was analysed based on these counts for the entire period since the start of counts to 2011/2012 to elucidate whether any changes had occurred. For information about changes in numbers and distribution in staging and wintering geese see Nilsson (2013).

\section{Study area}

The study area comprises the south-western part of the province of Skåne (hereafter SW Scania), the southernmost tip of the Scandinavian Peninsula (Figure 1). The main soil type is moraine with different proportions of clay (Germundsson \& Schlyter 1999). The annual precipitation ranges from $550 \mathrm{~mm}$ at the coast to $750 \mathrm{~mm}$ inland, of which $10-20 \%$ comes as snow. The coastal areas are situated south of the $-0.5^{\circ} \mathrm{C}$ isotherm and the inland areas south of the $-2.0^{\circ} \mathrm{C}$ isotherm. More than $60 \%$ of the total land area is used for agriculture and the main crops are cereals, sugar beet Beta vulgaris vulgaris var. altissima and oilseed rape Brassica napus, while potatoes Solanum tuberosum are grown mainly in the northern and eastern parts (Germundsson \& Schlyter 1999). Cultivated and natural grasslands are mainly found in the eastern part of the study area and along the coast.

Major changes in farming techniques and practices benefitting staging and wintering geese in SW Scania took place well before the counts started in the 1977/1978 season. Most important among these changes were the introduction of mechanical harvesting methods for cereals, potatoes and sugar beet (Myrdal \& Morell 2011), methods producing large amounts of harvest spill for feeding geese. Other important factors for the geese were removal of cultivation obstacles (e.g. hedges, stone walls, ditches and field roads) and amalgamation of fields into larger units (Gerell 1988), creating large fields with good all-round visibility for feeding geese; and an increase in the acreage of winter wheat (Statens jordbruksverk 2011), providing food for the geese during winter.

Some new crops, varieties, techniques and practices of importance for autumn staging and wintering geese were introduced during the study period. In 1993, triticale Triticosecale rimpauii was introduced as a new crop in SW Scania (Statens jordbruksverk 2011). Maize Zea mays and carrots Daucus carota became crops of local importance. More palatable varieties of rape, double-low with low erucic acid and glucosinolate content, were introduced in the 1980s (Ingerup 1992). The proportion of the arable land removed from production as set-asides varied greatly among years (Söderberg 2006, Statens jordbruksverk 2011). After the publication of the results of field tests starting in 1979 farmers started to saw rape with no-till (Pettersson 2009, Gunnarsson 2012). As a consequence of the concentration of the Swedish sugar production to a single factory, at Örtofta in SW Scania, the period during which the farmers could deliver sugar beets was extended to four months, from mid-September to mid-January (www.nordicsugar.se). Several fields of minor importance for feeding geese, both

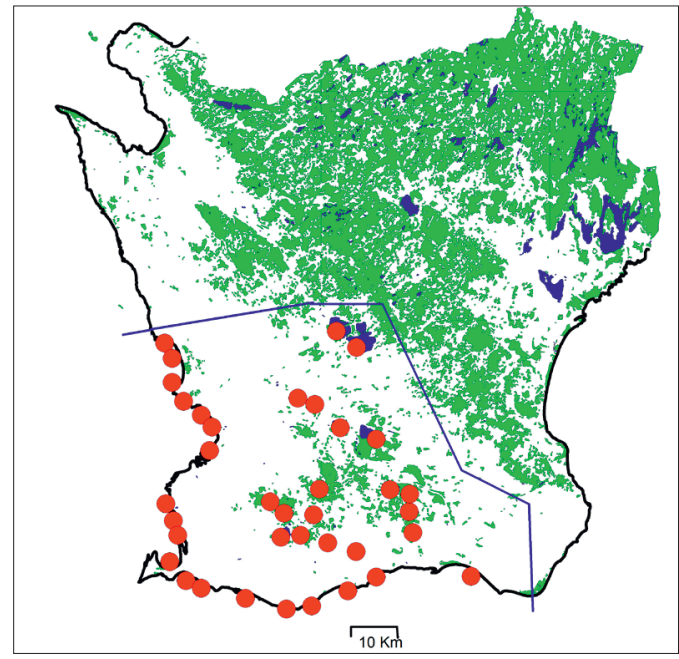

Figure 1. Map of Scania showing the borders of the study area (blue line). Red dots show the geographical positions of the night roosts regularly used by the geese.

Karta över Skåne med undersökningsområdet markerat (blå linje). Röda prickar markerar viktiga nattplatser. 
at the coast and inland, were planted with energy forest (Weih 2006).

At the October counts, stubbles were still available to a large extent, together with the first harvested sugar beet fields. In November, the stubbles were mostly ploughed or of little value for the geese. Harvested sugar beet fields, and in some areas harvested fields with carrots and potatoes, offered rich food sources for the geese, together with sprouting autumn-sown cereals. In January, available field types were winter cereals, winter rape and natural grasslands, and in later mild winters, also fields with sugar beet remnants.

Several lakes in SW Scania were drained or the water tables lowered during the period 1840-1940 (Svenskt vattenarkiv 1995). Most of the remaining lakes, as well as a few of the rivers and several sites along the coast, have been used as night roosts by autumn staging and wintering geese (Nordqvist 1947, Mathiasson 1963, Nilsson \& Persson 1984, 1991). Lake Näsbyholmssjön, one of the drained lakes, was partially restored in 2004 (Persson 2011). During the study period, several small waters were restored or constructed in SW Scania (Andersson et al. 2005). Most of these waters can be used as day roosts by geese, some of them also as night roosts.

\section{Material and methods}

Field choice of geese was determined in connection with mid-monthly counts in autumn (October and November) and in winter (January), 1977/19782011/2012. In all but a few cases, the field-work was carried out by one of the authors (HKP) over the entire study period. All areas known to be frequented by geese in SW Scania (Figure 1) were covered and all encountered flocks were recorded separately. Except for a flock of Bean Geese at River Tolånga in January before 2006 (Kampe-Persson 2010), a few flocks of Canada Geese at Landskrona and Barsebäck in January in some years and maybe a few flocks of Barnacle Geese in October during the last six years of the study (Kampe-Persson 2013a), there are good reasons to assume that no flocks of importance were overlooked. For each flock, numbers of the different species (and subspecies) were counted and recorded together with the field type used. The field type was registered as detailed as possible, i.e. not only information about the actual crop but also if it was harvested, if stubbles were harrowed, if oilseed rape was sown with no-till, and so on. To minimise the risk of scaring the feeding geese, field types were identified from the same distance as the geese were counted. For that reason, it was usually impossible to separate stubbles of barley Hordeum vulgare, wheat Triticum aestivum and triticale. When the feeding grounds were snow-covered, it was often impossible to identify any field types at all. Geese occurring at a roost site during the count were not ascribed to any field type.

When disturbed while feeding on sugar beet remains, the geese usually seek refuge on a stubble field, on a field with an autumn-sown crop, on grassland or at a roosting site. For instance, all hunting affecting large numbers of geese took place in sugar beet fields. In the middle of the day, the geese usually remained on the other field or at the roost for a long time before returning to the sugar beet field. In such cases, the geese might have been noted for the field type of the refuge or no field type at all, even though almost all feeding that day was made on fields with sugar beet remains. Therefore, percentages for sugar beet should be regarded as minimum values, while those for stubble, cereal, rape and grass should be regarded as maximum values.

In the analyses we separated the following six field types: sugar beet (harvest spill and a few cases of un-harvested beets), potatoes (harvest spill), rape (autumn-sown oilseed rape), stubble (cereal stubbles, mainly of wheat but also of rye Secale cereale, oats Avena sativa, barley and triticale, though the last-mentioned only since 1993), cereal (autumn-sown cereals, mainly wheat) and grass (both natural and cultivated grasslands). Cultivated grasslands were established as sownin crops, such as clover Trifolium pratense, T. hybridum and T. repens, lucerne Medicago sativa, and M. lupulina, vetch Vicia sativa, sweet-clover Melilotus sp., birdsfoot trefoil Lotus corniculatus, kidneyvetch Meliolotus vulneraria and grass $P h$ leum pratense, Festuca pratensis, F. arundinacea, F. rubra, F. ovina, Poa pratensis, $P$. palustris, $P$. trivialis, Bromus inermis, B. arvensis, Dactylis glomerata, Cynosurus cristatus, Lolium perenne, L. multiflorum, Arrhenatherum elatius, Alopecurus pratensis and Agrostis stolonifera (Bergelin et al. 1959, Halling 2005, Wiman 2012). The overall use of other field types was too low to be shown in the graphs. Instead, the use of red beet Beta vulgaris vulgaris var. vulgaris (harvest spill), carrots (harvest spill and a few cases of carrots in storage clamps), maize (stubbles and a few cases of un-harvested maize), wheat (un-harvested), peas Pisum sativum (harvest spill), newly-sown winter 
wheat, set-asides and ploughed fields will be mentioned in the text.

Due to large between-year variations the field choice data were grouped into five-year periods to better elucidate the long-term patterns. Moreover, the data for October and November were grouped together as we did not find any major differences in field utilisation between the two months. For each of the five most numerous species, two graphs illustrating the selection of feeding areas in autumn (October-November) and winter (January), respectively, are shown. Count data for SW Scania are given as five-year means as a background to the field choice data. For details, see Nilsson (2013).

The term Bean Goose in the field choice data refers to Taiga Bean Goose Anser fabalis fabalis (Kampe-Persson 2011).

\section{Results}

\section{Bean Goose Anser fabalis}

When the counts started in 1977/1978, SW Scania was still an important staging area for Bean Geese during the autumn (Figure 2, Nilsson 2013). Over the years the numbers seen in October decreased markedly to a very low level. November totals also decreased but five-year means seem to have stabilized at between 2000 and 4000 individuals. Means for the winter during the first five five-year periods were around $8000-10000$ with higher values for the last two five-year periods in spite of two cold winters during the last period.

When autumn counts started about $40 \%$ of the Bean Geese were found on harvested sugar beet fields with autumn-sown cereals as the second

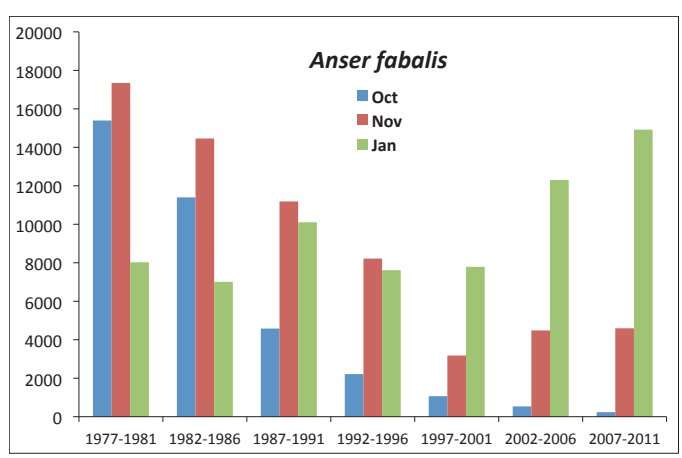

Figure 2. Five-year means for staging and wintering Bean Geese Anser fabalis in SW Scania.

Fem-års-medelvärden för antalet rastande och övervintrande sädgäss Anser fabalis i sydvästra Skåne.

most important field type (Figure 3). During the years the use of sugar beet fields by autumn staging Bean Geese increased to between 60 and $80 \%$ of all feeding inidividuals. In the last five-year period, the use of sugar beet was a little lower but a proportion of the field use was instead on harvested potato fields. Other field types were only used to a small extent. In addition to the field types shown in Figure 3, Bean Goose flocks fed on carrots on a few occasions, but this was a local feature, since carrots were not a common crop in the area.

In January, winter cereals dominated the field choice quite markedly during the first three fiveyear periods (Figure 3) with other crops except grass being used only to a very small extent. A marked change in field choice followed and during the last twenty years potato and sugar beet spill amounted to $40-50 \%$ of the field use. Potatoes dominated during 1993-2002 and sugar beet dur-
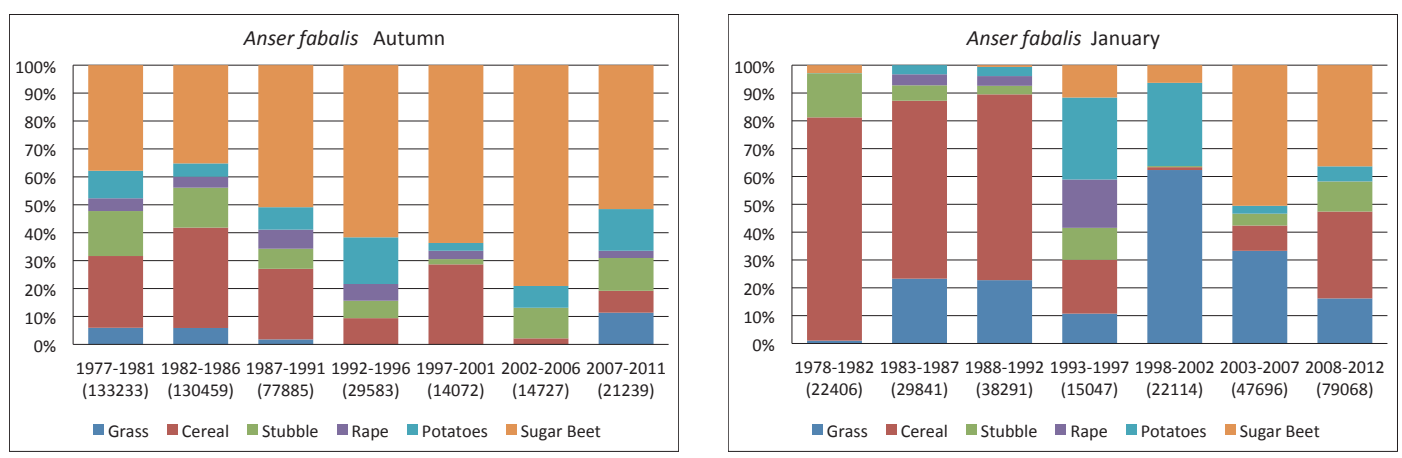

Figure 3. Field choice of staging (October and November) and wintering (January) Bean Geese Anser fabalis in SW Scania in different five-year periods. Numbers counted are shown in brackets.

Fältval för rastande (oktober och november) och övervintrande (januari) sädgäss Anser fabalis $i$ sydvästra Skåne. Antalet inräknade individ visas inom parentes. Sugar beet $=$ sockerbetor, potatoes $=$ potatis, rape $=$ raps, stubble $=$ spannmålsstubb och grass $=$ gräsmarker . 


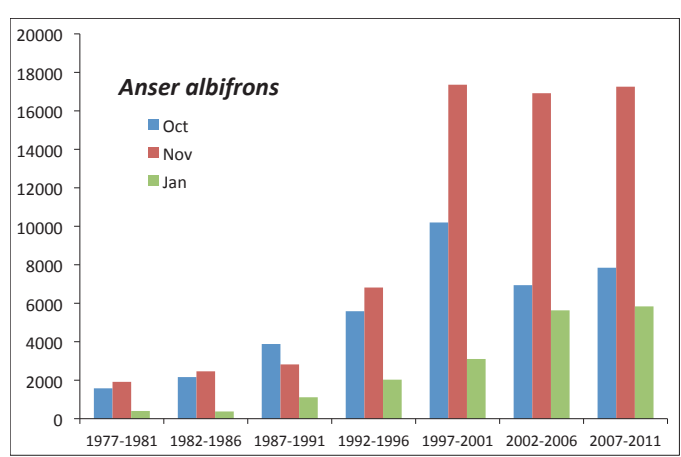

Figure 4. Five-year means for staging and wintering Whitefronted Geese Anser albifrons in SW Scania.

Fem-års-medelvärden för antalet rastande och övervintrande bläsgäss Anser albifrons i sydvästra Skåne.

ing 2003-2012. Even in January, Bean Geese were on some occasions seen feeding on carrots.

\section{Pink-footed Goose Anser brachyrhynchus}

The Pink-footed Goose occurred in low numbers, mainly singly, in the Bean Goose flocks during the entire study period. By that, their field choice was very similar to that of the Bean Goose.

\section{White-fronted Goose Anser albifrons}

The White-fronted Goose belongs to the species of geese where both staging and wintering numbers in SW Scania have increased over the study period (Figure 4). Whereas the mean numbers staging in autumn seem to have stabilized during the last three five-year periods, there has been a steady increase in the numbers staying during the winter, probably due to a se-

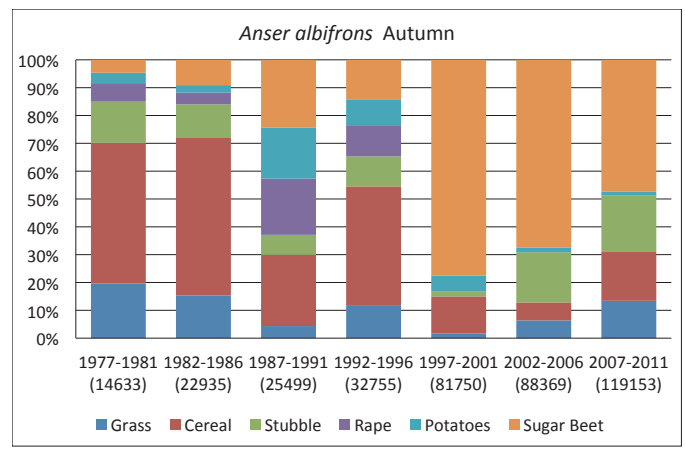

ries of mild winters (for further discussion, see Nilsson 2013).

During the first ten years of goose counts about $70 \%$ of the field use for the White-fronted Geese in autumn was on winter cereals and grassland (Figure 5). A smaller proportion of the White-fronted Geese were also found on stubble fields. When the counts started the use of sugar beet spill was not important, but this field type increased in importance for the staging White-fronted Geese and during 19972006, 70-80\% were found on sugar beet spill. This proportion was smaller in 2007-2012, when the use of winter wheat and grassland was somewhat higher.

In January, the majority of the White-fronted Geese was found on winter cereals or grassland during the first five-year periods. Rape was used to some extent during 1988-1997 but was rarely used in the other years. During the latter part of the study period winter cereals decreased in importance and a higher proportion of the White-fronted Geese were found on grassland. In 2003-2012, sugar beet spill increased in importance for the wintering White-fronted Geese with $20-40 \%$ of the field use.

\section{Greylag Goose Anser anser}

The Greylag Goose is a common breeding species in SW Scania (Nilsson \& Persson 1994) but the area is also an important staging and (in recent years) wintering area for the species. The field choice and habitat utilisation of the Greylag Goose during summer and early autumn have been presented by Persson (1989) and Nilsson \& Persson (1992, 1998).

When the regular goose counts started in $1977 / 1978$ very few Greylag Geese were found in

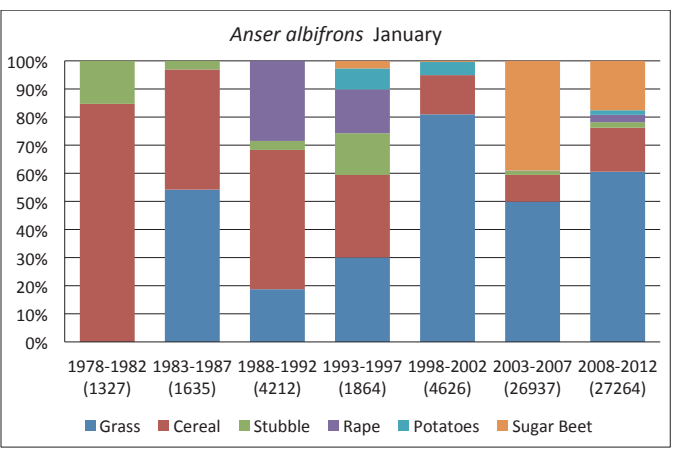

Figure 5. Field choice of staging (October and November) and wintering (January) White-fronted Geese Anser albifrons in SW Scania in different five-year periods. Numbers counted are shown in brackets.

Fältval för rastande (oktober och november) och övervintrande (januari) bläsgäss Anser albifrons $i$ sydvästra Skåne. Antalet inräknade individ visas inom parentes. För beskrivning av fälttyper, se Figur 3. 
South Sweden. Special September counts started in 1984 (see Nilsson 2013) but during the first years numbers in SW Scania and the rest of Sweden at the October and November counts were very low. October numbers and later November numbers did, however, start to increase as the Greylag Geese were staying for longer periods in the country (Nilsson 2006) and eventually they also started to winter in larger numbers, especially in SW Scania (Figure 6).

During 1982-1986, only few Greylag Geese were included in the counts, most being found on autumn-sown cereals and stubble. From 1987-1991 and onwards, the majority of the Greylag Geese in autumn were found feeding on spill from the sugar beet harvest (Figure 7), with only a small proportion on other field types. In addition to the field types illustrated in the graphs, a number of Greylag Geese have been found feeding on carrots or unharvested cereals in some areas in some years. In October 2006, no less than 20000 individuals were feeding in a flooded field with un-harvested wheat at Lake Vombsjön. Recently, Greylag Geese have also been found locally to use fields with maize stubble, but this was not observed so often during the regular surveys.

The habit of the Greylag Geese to stay in Sweden and especially in SW Scania over the winter is new. Very few wintering individuals were found except during the last ten years when wintering birds increased in numbers, with January totals being around $25 \%$ of the September count in some years (Figure 6, Nilsson 2013). About 50\% of the wintering Greylag Geese were found on fields with sugar beet spill, and other field types commonly used were winter wheat and grassland.

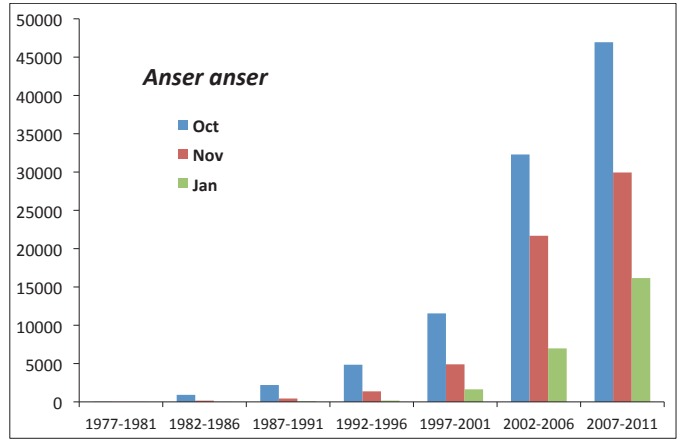

Figure 6. Five-year means for staging and wintering Greylag Geese Anser anser in SW Scania.

Fem-års-medelvärden för antalet rastande och övervintrande grågäss Anser anser i sydvästra Skåne.

\section{Canada Goose Branta canadensis}

During the first years of goose counting in Sweden, Canada Geese were common during winter in SW Scania, whereas few were seen in the area during October and November (Figure 8). As for the other goose species an increase was noted over the years with January five-year means for the area reaching about 25000 and November means being 11000 15000 for the last three five-year periods. October counts also increased but were still quite low.

During the first fifteen years, when only small numbers of Canada Geese were found in autumn, most of them were feeding on fields with autumnsown cereals. Later, the field choice changed to sugar beet, which has dominated in the autumn for the last twenty years (Figure 9).

In January, the majority of the Canada Geese were feeding on autumn-sown cereals but during
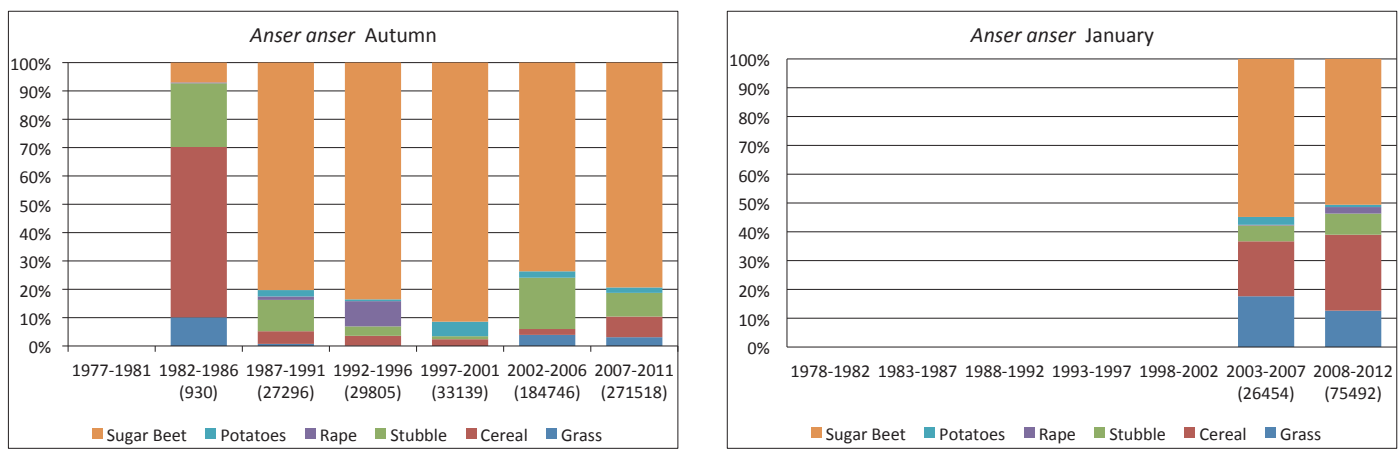

Figure 7. Field choice of staging (October and November) and wintering (January) Greylag Geese Anser anser in SW Scania in different five-year periods. Numbers counted are shown in brackets.

Fältval för rastande (oktober och november) och övervintrande (januari) grågäss Anser anser $i$ sydvästra Skåne. Antalet inräknade individ visas inom parentes. För beskrivning av fälttyper, se Figur 3. 


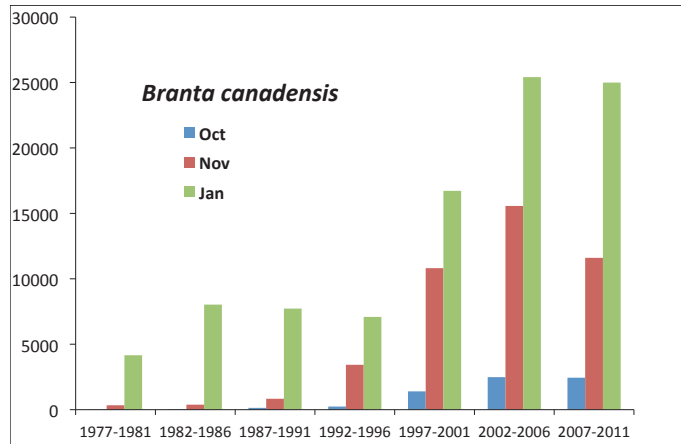

Figure 8. Five-year means for staging and wintering Canada Geese Branta canadensis in SW Scania.

Fem-års-medelvärden för antalet rastande och övervintrande kanadagäss Branta canadensis $i$ sydvästra Skåne.

the last fifteen years sugar beet spill increased in importance, with 50 and $70 \%$, respectively, found on sugar beet spill during the last two five-year periods. In 1993-1997, a large proportion of the Canada Geese were reported on fields with rape. Compared to the other species discussed here, rape, especially fields sown with no-till, was of larger importance for the Canada Geese during winter. In January 2010, more than one third of the Canada Geese were feeding on rape.

\section{Barnacle Goose Branta leucopsis}

During the first fifteen years of goose counts, the number of Barnacle Geese counted in SW Scania during autumn was very low but during the last fifteen years numbers increased dramatically (Figure $10)$, partly due to changes in the migration patterns (Nilsson 2013). Wintering totals were low except during the last few years, although the five-year mean for the last period was around 3000 com-

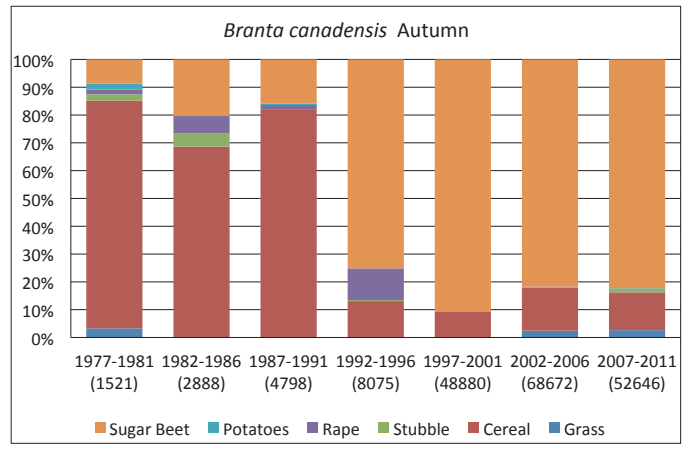

pared to more than 50000 in October and more than 30000 in November during the same period.

During the first ten years, when the species was relatively uncommon, most Barnacle Geese were found on autumn-sown cereals and grassland (Figure 11). The use of sugar beet was unimportant during the first years and mostly restricted to small groups of Barnacle Geese in flocks of more numerous goose species. From 1992-1996 and onwards, the use of sugar beet spill increased to between 50 and $80 \%$ of the field utilisation. Other field types frequently used were winter wheat and stubbles.

Wintering Barnacle Geese during 2003-2007 were mostly found on sugar beet spill with winter wheat and grassland as their second choice. In 2008-2012, with two cold winters, winter wheat and grassland dominated.

\section{Discussion}

The agricultural revolution in the 19th century, with several new crops (Wiman 2012), and the mechanisation during the post-war period (Myrdal \& Morell 2011) has largely changed the agricultural landscape in SW Scania. However, it was a slow process and it took at least two decades for each new crop or technique to be accepted by a majority of the farmers. This time aspect is worth keeping in mind when discussing how the geese responded to each of them. Plant breeding and an increased use of fertilizers has substantially improved the productivity of the different crops, without it being possible to relate the effects to a specific period (Statens jordbruksverk 2011).

Owen (1980) discussed the feeding ecology of different goose species and related this to the mor-

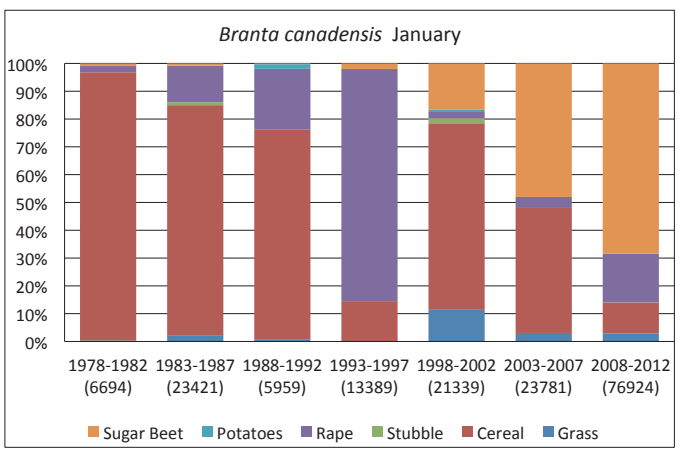

Figure 9. Field choice of staging (October and November) and wintering (January) Canada Geese Branta canadensis in SW Scania in different five-year periods. Numbers counted are shown in brackets.

Fältval för rastande (oktober och november) och övervintrande (januari) kanadagäss Branta canadensis $i$ sydvästra Skåne. Antalet inräknade individ visas inom parentes. 
phology of the bill. According to this classification, the Greylag Goose with its heavy and strong bill was adapted to feed on marshes and mudflats, digging up rhizomes of species like Scirpus. Another group of geese were those considered to have allpurpose bills suitable for grazing, grubbing and seed stripping. Of the species discussed here the Bean Goose, White-fronted Goose and Canada Goose were included in this group. Finally, the Barnacle Goose and some other species with short bills were considered to be adapted to rapid picking and very efficient in grazing short grass swards. However, when Owen (1980) published his review the geese had already changed their feeding habits and field choice appreciably and the different species were to a large extent found on agricultural land with different types of crops used for feeding. But to some extent they still used their natural habitats during part of the non-breeding season. For instance, the Greylag Geese of North-west Europe (including Sweden) to a large extent wintered in the Guadalquivir Marismas in South-west Spain during these years (Andersson et al. 2001, Nilsson 2006). In their Spanish winter quarters, Norwegian Greylag Geese fed on natural grasslands, while the other Greylag Geese to a large extent used Scirpus areas for feeding (Kampe-Persson 2002). When their normal feeding grounds were flooded both populations switched to winter cereals, the Norwegian birds to fields rich in weeds and the others to fields with luxuriant seedlings. Greylag Geese also used the Dutch Delta for staging and to some extent wintering during those years, mainly relying on Scirpus and other marsh plants for food (Loosjes 1974, Castelijns et al. 1998).

When Gunnar Markgren made his classical study of wintering geese in SW Scania in the 1950s, the

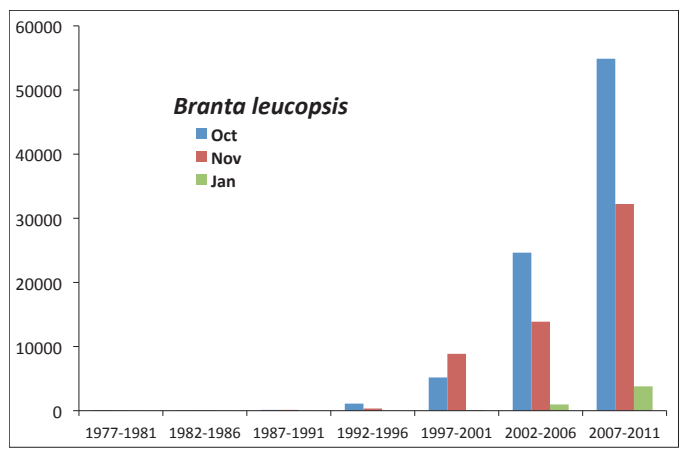

Figure 10. Five-year means for staging and wintering Barnacle Geese Branta leucopsis in SW Scania.

Fem-års-medelvärden för antalet rastande och övervintrande vitkindade gäss Branta leucopsis i sydvästra Skåne.

prevalent opinion was that wintering Bean Geese fed on agricultural fields. However, the geese were mainly feeding on natural grasslands, $51 \%$ of the feeding time in autumn and $56 \%$ in winter, with another $22 \%$ of the time in autumn and $12 \%$ in winter in fields of clover (Markgren 1963). The remaining $30 \%$ of the feeding time, in both autumn and winter, was equally devoted to feeding in cereal stubbles, winter cereals and ploughed fields. The White-fronted Goose was feeding in natural grasslands to an even larger extent, $80 \%$ in autumn and $98 \%$ in winter (Markgren 1963).

Cultivated grasslands have been grown in SW Scania since the 18th century (Wiman 2012). Data for natural and cultivated grasslands were lumped together in our study but even so, grasslands were of little importance for all species in autumn. In mild winters, however, large numbers of Bean and Whitefronted Geese and quite large numbers of Greylag and Barnacle Geese were found in natural grasslands.
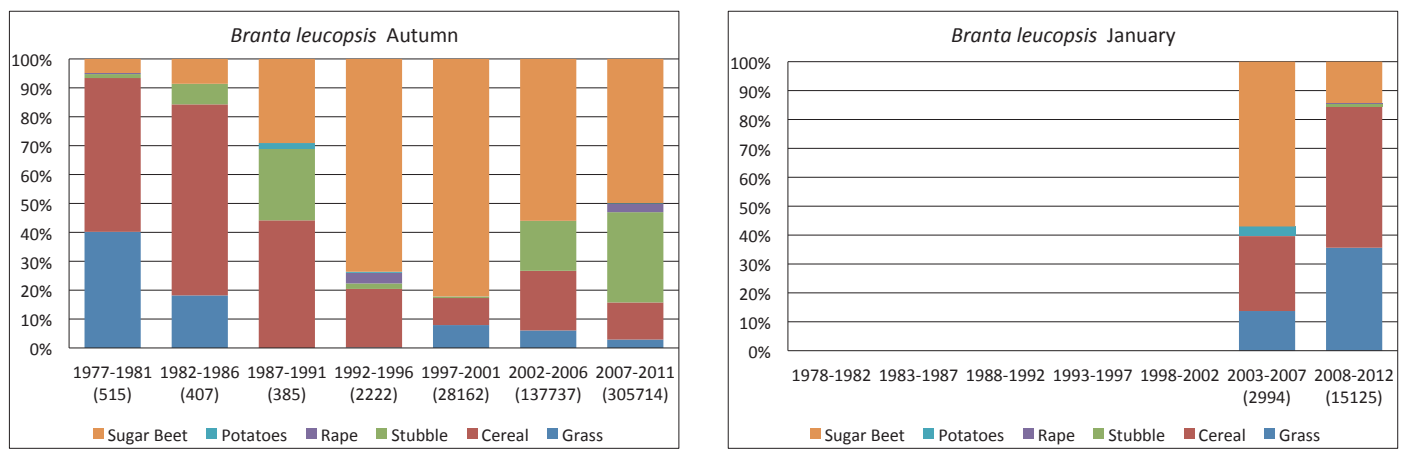

Figure 11. Field choice of staging (October and November) and wintering (January) Barnacle Geese Branta leucopsis in SW Scania in different five-year periods. Numbers counted are shown in brackets.

Fältval för rastande (oktober och november) och övervintrande (januari) vitkindade gäss Branta leucopsis $i$ sydvästra Skåne. Antalet inräknade individ visas inom parentes. 
When the geese started to feed on cereal stubbles in SW Scania is unknown. In the beginning of the 19th century, the Barnacle Goose relied so heavily on oat stubbles during autumn staging that the species was named Hafregås, "Oat Goose" (Nilsson 1835). Of unknown reasons the Barnacle Goose ceased to stage in the area in the mid 19th century (Kampe-Persson 2013a). While the Bean Goose is scientifically named after the field bean Vicia faba, the Swedish name is sädgås, "Cereal Goose". That name strongly suggests that this species started to feed in cereal fields long before the modern harvesters produced an abundance of spilled grain to feed on. Feeding on newly-sown barley, rye seedlings and ripening barley was mentioned by Nilsson (1821). The first harvesters came in the middle of the 1940s but many farmers continued for decades to harvest in a more traditional way. The reason was that they wanted to make full use of the straw for their cattle. But also when harvesters were in common use, there were large differences among areas; wheat stubbles in SW Scania had more spill than in East Germany in the early 1980s (Erich Rutschke pers. comm.).

Cereal stubbles can offer the geese three kinds of food; spilled grain, weeds and sprouting spilled grain, and sometimes also sown-in crops. Add to this that the harvesting time can differ from year to year, as well as the weather conditions during the harvesting period. In other words, cereal stubbles can vary greatly from year to year, especially during the time of year considered here. In the late 1980s, cereal stubbles in SW Scania were heavily utilised by Greylag Geese in September and early October (Persson 1989, Nilsson \& Persson 1992). The number of Greylag Geese in the study area has increased substantially since then (Nilsson 2013), so therefore only a little spilled grain is now normally left in mid-October.

In the beginning of the 19th century, Bean Geese were mainly feeding on winter rye during wintering in SW Scania (Nilsson 1835). One and a half century later, the species was not using this field type at all and other winter cereals only to a low extent (Markgren 1963). Thereafter, the feeding pattern changed markedly and during the first 15 years of our study winter cereal was the main field type for Bean Geese, White-fronted Geese and Canada Geese. This field type was also used to a large extent in autumn, especially by the White-fronted Geese, Canada Geese and Barnacle Geese. In recent years, sugar beet spill has taken over as the most important field type in autumn while sugar beet spill and grassland are the most important in winter. The largest importance of the winter cereal is probably its availability. Whenever the harvest spill is depleted or ploughed down there are always fields with winter cereals for the geese to switch to. And also after heavy snow fall, windblown fields continue to offer a rich food supply. Occasionally, winter cereals are utilised as a food source already as newly-sown crops, when Greylag Geese follow the rows and pick the seeds (Persson 1989, Nilsson \& Persson 1992). However, as winter cereals usually are sown before the mid-October count, this behaviour was rarely observed during this study.

Potatoes have been grown on light, sandy soils in SW Scania since the first years of the $19^{\text {th }}$ century (Wiman 2012). However, before the farmers started to use modern harvesting machinery, potato fields only attracted feeding geese after that they had been ploughed. In such fields, Bean Geese fed on rhizomes of weeds like Agropyron repens and potatoes left in the ground (Nordqvist 1947, Markgren 1963). The first time geese were reported to feed on potatoes in a harvested field was in 1965 (Mellquist $\&$ Nilsson 1968). The inclusion of potato in the diet of the Pink-footed Goose Anser brachyrhynchus in Britain occurred as a result of their habit of grazing winter wheat seedlings because winter wheat followed potatoes in crop rotation (Kear 1963). The Bean Goose in SW Scania might have learned to feed on potatoes in a similar way. The varying use of potato fields in this study was largely due to the availability of sugar beet spill, because all goose species showed a higher preference for sugar beet remnants than for potatoes.

Sugar beet has been a very important crop in SW Scania since the 1880s (Wiman 2012). However, as long as the harvesting was done manually this crop was of no interest to the geese and Markgren (1963) stated that Bean Geese never visited sugar beet fields. With the introduction of mechanical harvesting methods in the 1960s the Bean Geese quickly learned to exploit this rich food source (Persson 1982). Fields with sugar beet remnants have dominated the field choice of the Bean Goose in autumn since then and during the last ten years also during the winter (this study). The winter use of sugar beet spill reflects a change in the length of the harvesting season in recent years; in some years farmers still harvested sugar beet after the middle of January. Sugar beet remnants have become the most important food source in autumn also for the other four goose species discussed here but it took somewhat longer for them to switch to this field type.

For the Greylag Goose, this switch was possible 
to follow in detail. When the regular goose counts started in Sweden during 1977/1978, the number of staging Greylags in SW Scania in October and November was quite small (although increasing) and the first data illustrating the field choice during these months were obtained during the period 1982-1986, although data are also available from studies on a local breeding population, including field choice and local movement patterns studied during 1985-1987 (Persson 1989, Nilsson \& Persson 1992). In these years, the Greylags mainly remained in the inland lake areas, feeding on fields with peas, stubbles and un-harvested cereals when available. Sugar beet were not grown in the lake study area. The cold winter of 1987 led to a delayed harvest and the post-breeding flocks moved to Foteviken at the coast, an area with sugar beet fields and some small flocks started to use this food source (Nilsson \& Persson 1992). This food preference developed rapidly and in the coming years a large proportion of the geese from the inland area moved to the coast and stayed here feeding on sugar beet spill, which probably led to a much later departure compared to earlier years (Nilsson 2006). It may be noted that the Greylags from the area regularly fed on sugar beet spill during staging in the Netherlands before this habit started in Sweden (see e.g. Phillippona 1985)

Oilseed rape has been grown in Sweden since the 18 th century but it was not mentioned as a food source for geese in late autumn or winter before this study (Nordqvist 1947, Markgren 1963, Mellquist \& Nilsson 1968, Nilsson 1968). In early autumn in the province of Blekinge, however, Canada Geese regularly fed on rape when the plants had 2-4 leaves (Nilsson 1968). The introduction of more palatable varieties in the 1980 s $(99 \%$ of the Swedish acreage was sown with double-low varieties in 1990; Ingerup 1992), did not lead to a more marked utilisation of rape by feeding geese. Winter rape was mainly used when the ground was snow-covered as rape is often the only crop available above the snow.

Among the new crops in SW Scania, maize has, just as in other countries, the potential of becoming of regional importance for feeding geese. Up to now, mainly Whooper Swans Cygnus cygnus and Greylag Geese have been found feeding in un-harvested and harvested maize fields, and only locally. Carrots and red beet are grown by few farmers, so these field types will most likely continue being of only local importance. It is not known to which extent triticale was used by feeding geese due to difficulties in separating the cereal species during the counts. Crops like grass-seed and peas are usually harvested too early to be of any interest for feeding geese during the time of year considered here, but peas were important for local Greylag Geese during late summer and early autumn in SW Scania (Persson 1989, Nilsson \& Persson 1992).

SW Scania seems to fulfil all necessary requirements for a region of importance for staging and wintering geese; availability of safe night roosts, rich food supplies situated not too far from the roosts, feeding grounds with good all-round views, low levels of disturbance and a favourable climate (Owen 1980, Persson 1989). The region is rich in roosting sites and most lakes are large enough to be used as night roosts also when they are covered by ice. As the total number of geese in SW Scania in autumn and winter has increased many-fold during the study period (Nilsson 2013) and the different species use the same field types (this study), often feeding in large mixed flocks, the food supply of each field is depleted much faster now than earlier. Most of the time, however, the geese feed within five $\mathrm{km}$ of their roosts, before depletion and ploughing force them to seek food further away. In winter, Canada Geese were regularly found feeding up to $17 \mathrm{~km}$ and Bean Geese up to $15 \mathrm{~km}$ from their roosts (Nilsson \& Persson 1991, this study). However, Greylag Geese were found to fly up to $14 \mathrm{~km}$ to reach a very profitable food source, e.g. a field with harvested peas, also in autumn.

A factor reducing the availability of the fields for feeding geese are actions taken by farmers to keep them away from growing crops, mainly winter cereals. Occasionally, farmers actively scared the geese away from the fields but usually they just put up traditional scaring devices, such as scare-crows, a car parked in the middle of the field or raptor silhouettes on high moving masts (cf. Fog 1982a, Fog 1982b). As hunting of geese is very local in SW Scania and the overall hunting pressure is quite low most geese have lost their former shyness. Individuals of all species can nowadays be seen feeding quite close to houses, hedges and forest edges, while they avoid power lines and wind-turbines.

Field choice, as it was presented in this study, does not by necessity show the food preferences of the geese. To achieve that, also data about the availability of the different field types are needed (cf. Persson 1989). However, a strong indication of the food preferences of the geese was obtained by comparing their field choice whenever they had access to more than one field type. By comparing fields with different unused food sources the following preference list was obtained (the most- 
preferred food first): un-harvested wheat - spilled grain - sugar beet spill - potato spill - winter cereal - winter rape (in each comparison, acreage of the preferred field type was less than that of the other field type(s), sample size was more than 10 000 birds, of which $95-100 \%$ were found on the preferred field type). This preference list can be used to mitigate conflicts between geese and farmers. The most important message is that geese during the months October-January rarely cause any problems for farmers in this part of Sweden. In general, as long as the geese have access to harvest spill they show little interest in autumn-sown crops. And winter cereals can sustain high grazing pressures without negative effects (Jönsson 1982). In oilseed rape, on the other hand, already low grazing pressures can cause large losses of yield (Jönsson 1982). As rape fields are mainly used when no other field types are available, usually because they are snow-covered, a good strategy would be to concentrate efforts of scaring the geese to such circumstances. With regard to feeding on other field types, feeding in un-harvested sugar beet fields has become more common during the autumn in recent years, especially at coastal sites, but that habit is probably of little economic significance except maybe locally. Carrots, on the other hand, are very susceptible to feeding by geese before harvest (Kear 1990) but such feeding was not observed during this study.

The large variety of food sources most goose species utilise in modern agriculture nowadays demonstrates a very large adaptability in these species. Before geese started to feed in improved grasslands and farmland, each species and subspecies occupied its own feeding niche and the winter distributions were almost non-overlapping (Owen 1980, Kampe-Persson 2002). Food availability in winter was probably a limiting factor for most goose populations in those times (Owen 1980). The proportion of the total food intake coming from improved grasslands and farmland during the nonbreeding season has increased successively since the mid 18th century (Owen 1980, Kear 1990, this study). In autumn and winter in SW Scania, five goose species have attained a very wide, though not identical, food niche (this study). In this region, the Canada Goose is the only species feeding on bottom vegetation in shallow coastal waters, the Greylag Goose is the only species feeding on Scirpus, while the most numerous species on inland natural grasslands in winter were Taiga Bean Goose and White-fronted Goose. A closer inspection of food items taken might show differences between the
Taiga Bean Geese and the White-fronted Geese however. Seemingly, the five species have widened their food niches in a similar way at the same time as each species has retained its original niche unintruded. The original feeding niche can, providing it still exists, act as a refuge the day competition excludes a taxon from the shared niche. Whether or not food competition occurs among wintering geese today is not known.

When feeding on harvest spill and autumnsown crops, as all geese mainly do in SW Scania nowadays (this study), the birds are offered large amounts of food per hectare. However, reliance on a few monocultures for feeding in autumn and winter makes the geese susceptible to changes of varieties grown or farming technique. Agricultural changes can occur quickly and unexpectedly, such as when a decision in the European Union resulted in the cessation of sugar beet production in Latvia (Piskunova \& Alsina 2010). At the same time, climate change may create new feeding opportunities for staging and wintering closer to the breeding grounds (Nilsson 2013.). If the trend during the study period continues, most Taiga Bean Geese and Canada Geese might remain and winter north of SW Scania in the future while the numbers of wintering White-fronted Geese, Greylag Geese and Barnacle Geese will increase in the study area. Very likely, instead of the Taiga Bean Goose, the Tundra Bean Goose Anser fabalis rossicus and maybe also the Pink-footed Goose Anser brachyrhynchus, will become a wintering bird in this part of Sweden. The Tundra Bean Goose has started to winter in Denmark during the last decade (Pihl \& Vikstrøm 2006, Stefan Pihl unpubl.) and at Lake Hammarsjön in North-east Scania during the last few mild winters (Kampe-Persson 2013b).

\section{Acknowledgements}

The regular goose counts in Sweden started during a Nordic Goose Project supported by the Nordic Council for Wildlife Research and have over the years been supported by the Swedish Hunters Association ("Jägartjugan"). During the early years studies of the habitat selection of geese in the agricultural landscape were supported by grants from the Swedish Environmental Protection Agency and from Carl Trygger's Foundation for Scientific Research. 


\section{References}

Andersson, J., von Barth, P., Månsson, J. \& Broström, A. 2005. Skånska småvatten nu och då - förändringsinventering med hjälp av flygbilder från 1940-, 1980- och 2000-talet. Länsstyrelsen i Skåne Län, Malmö.

Andersson, Å., Follestad, A., Nilsson, L. \& Persson, H. 2001. Migration patterns of Nordic Greylag Geese Anser anser. Ornis Svecica 11: 19-58.

Axelsson, K.-M. \& Modin, T. 2006. Viltbetesåkrar, utfodringsplatser och skrämsel - åtgärder för att förebygga viltskador av gäss och tranor vid Tåkern. Länsstyrelsen Östergötland, Linköping.

Bergelin, S.-E.S., Collinder, P., Hadding, A., Hanström, B., Hannel, S., Lenning, A., Moberg, I., Myhrman, G., Nyman, A., Olsson, B., Sahlgren, J. Stjernquist, P. \& Wieselgren, O. 1959. Nordisk Familjebok. Vol. 21. Förlagshuset Norden AB, Malmö.

Castelijns, H., Maebe, J. \& Van Kerkhoven, W. 1998. Greylag Geese in the "Verdronken Land van Saeftinghe" (Netherlands): numbers, trends and food. Oriolus 64: 90-102. (Flemish with English summary).

Edberg, R. 2003. Förvaltningsplan för grågås. Miljöenheten, Naturresursfunktionen, Länsstyrelsen i Skåne län, Malmö.

Fog, J. 1982b. Markskader forvoldt af gæs i Danmark. Pp. 79-82 in De svenska gässen: förekomst, ekologi, betesskador, jakt och vård (Svensson, S., ed.). Vår Fågelvärld, Supplement 9.

Fog, M. 1982a. Internationale erfaringer med hensyn til gåseskader og forebyggende deraf. Pp. 63-70 in De svenska gässen: förekomst, ekologi, betesskador, jakt och vård (Svensson, S., ed.). Vår Fågelvärld, Supplement 9.

Fox, A.D., Ebbinge, B.S., Mitchell, C., Heinicke, T., Aarvak, T., Colhoun, K., Clausen, P., Dereliev, S., Faragó, S., Koffijberg, K., Kruckenberg, H., Loonen, M.J.J.E., Madsen, J., Mooij, J., Musil, P., Nilsson, L., Pihl, S. \& van der Jeugd, H. 2010. Current estimates of goose population sizes in western Europe, a gap analysis and an assessment of trends. Ornis Svecica 20: 115-127.

Gerell, R. 1988. The avifauna of the farmland, a historical survey. Pp. 1-20 in De svenska gässen: förekomst, ekologi, betesskador, jakt och vård (Svensson, S., ed.). Vår Fågelvärld, Supplement 9. (Swedish with English summary).

Germundsson, T. \& Schlyter, P. 1999. Atlas över Skåne. Sveriges Nationalatlas. Lantmäteriet \& Sydsvenska Geografiska Sällskapet, Vällingby.

Gunnarsson, A. 2012. Direktsåddens dilemma - halm och spill. Svensk Frötidning 81(3): 31-34.

Hake, M., Månsson, J. \& Wiberg, A. 2010. A working model for preventing crop damage caused by increasing goose populations in Sweden. Ornis Svecica 20: 225-233.

Halling, M.A. 2005. Forage species for cutting, grazing and green fodder: varieties for south and central Sweden 2005/2006. Ekologi och växtproduktion, Swedish University of Agricultural Sciences, Uppsala. (Swedish).

Houlihan, P.F. 1986. The birds of Ancient Egypt. Aris \& Phillips, Warminster, UK.

Ingerup, M. 1992. Jämförelse mellan oljeväxtsektorn i Sverige och EG. Rapport 1992: 26. Jordbruksverket, Jönköping.

Jönsson, B. 1982. Gåsskador inom lantbruket i Skåne. Pp. 71-74 in De svenska gässen: förekomst, ekologi, be- tesskador, jakt och vård (Svensson, S., ed.). Vår Fågelvärld, Supplement 9.

Kampe-Persson, H. 2002. Anser anser Greylag Goose. BWP Update 4: 181-216.

Kampe-Persson, H. 2010. River Tolånga - a site of international importance for wintering Taiga Bean Geese Anser fabalis fabalis. Anser 49: 227-230. (Swedish with English summary).

Kampe-Persson, H. 2011. How large proportion of the Bean Geese counted in Sweden was made up of Taiga Bean Geese Anser fabalis fabalis? Ornis Svecica 21: 58-60. (Swedish with English summary).

Kampe-Persson, H. 2013a. Från havregås till sockerbetsgås - den vitkindade gåsen som höstrastfågel i södra Skåne. Anser 52: 00-00.

Kampe-Persson, H. 2013b. Staging and wintering Taiga Bean Geese Anser fabalis fabalis in North-east Scania, 1947-2013. Ornis Svecica 23: 00-00.

Kear, J. 1963. The history of potato-eating by wildfowl in Britain. Wildfowl 14: 54-65.

Kear, J. 1990. Man and wildfowl. T. \& A.D. Poyser, London.

Loosjes, M. 1974. Habitat use, disturbances and food of Greylag Geese Anser anser in a brackish tidal area. $\mathrm{Li}$ mosa 47: 121-143. (Dutch with English summary).

Madoz, P. 1849. Diccinario geográfico-estadístico-histórico de España y sus posesiones de ultramar. Vol. XII. Imprenta del Diccionario geográfico-estadístico-histórico de d. Pascual Madoz, Madrid.

Markgren, G. 1963. Migrating and wintering geese in southern Sweden. Ecology and Behaviour studies. Acta Vertebratica 2: 297-418.

Mathiasson, S. 1963. The Bean Goose, Anser fabalis (Latham), in Skåne, Sweden, with remarks on occurrence and migration through northern Europe. Acta Vertebratica 2: 418-533.

Mellquist, H. \& Nilsson, B. 1968. The Vomb area as a Halting and Wintering Habitat for Bean Goose (Anser fabalis). Vår Fågelvärld 27: 220-230. (Swedish with English summary).

Myrdal, J. \& Morell, M. 2011. The Agrarian History of Sweden: From 4000 BC to AD 2000. Nordic Academic Press, Lund.

Nilsson, B. 1968. Kanadagässens inverkan på höstsådda grödor och på den ekologiska balansen. Rapport till Viltforskningsrådet.

Nilsson, L. 2000. Changes in numbers and distribution of staging and wintering goose populations in Sweden, 1977/78-1998/99. Ornis Svecica 10: 33-49.

Nilsson, L. 2006. Changes in migration patterns and wintering areas of south Swedish Greylag Geese Anser anser. Pp. 514-516 in Waterbirds around the World (Boere, G.C., Galbraith, C.A. \& Stroud, D.A., eds.). The Stationary Office. Edinburgh, UK.

Nilsson, L. 2013. Staging and wintering goose populations in Sweden 1977/78-2011/12. Ornis Svecica 13: 3-45.

Nilsson, L. \& Persson, H. 1984. Non-breeding distribution, numbers and ecology of Bean Goose, Anser fabalis, in Sweden. Swedish Wildlife Research 13: 107-170.

Nilsson, L. \& Persson, H. 1991. Selection and exploitation of feeding areas by staging and wintering geese in southernmost Sweden. Ornis Svecica 1: 81-92.

Nilsson, L. \& Persson, H. 1992. Feeding areas and local movement patterns of post-breeding Greylag Geese Anser anser in South Sweden. Ornis Svecica 2: 77-90. 
Nilsson, L. \& Persson, H. 1994. Factors affecting the breeding performance of a marked Greylag Goose Anser anser population in south Sweden. Wildfowl 45: 33-48.

Nilsson, L. \& Persson, H. 1998. Field choice of staging Greylag Geese Anser anser in relation to changes in agriculture in South Sweden. Ornis Svecica 8: 27-39.

Nilsson, L. \& Persson, H. 2000. Changes in field choice among staging and wintering geese in southwestern Scania, south Sweden. Ornis Svecica 10: 161-169.

Nilsson, S. 1821. Ornithologia Svecica. Vol. 2. Apud J.H. Schubothium, Copenhagen.

Nilsson, S. 1835. Skandinavisk fauna. Foglarna. Vol. 2. C.W.K. Gleerups Förlag, Lund.

Nordqvist, G. 1947. Gäss i Skåne. Pp. 320-330 in Natur $i$ Skåne (Hanström, B. \& Curry-Lindahl, K., eds.). Bokförlaget Svensk Natur, Stockholm.

Oord, J.G. 2009. Handreiking Faunaschade. Faunafonds, Dordrecht, Netherlands.

Owen, M. 1977. The role of wildfowl refuges on agricultural land in lessening the conflict between farmers and geese in Britain. Biological Conservation 11: 209-222.

Owen, M. 1980. Wild Geese of the World. B.Y. Batsford, London.

Owen, M. 1990. The damage-conservation interface illustrated by geese. Ibis 132: 238-252.

Persson, H. 1982. Sädgässens fältval i Skåne. Pp. 75-78 in De svenska gässen: förekomst, ekologi, betesskador, jakt och vård (Svensson, S., ed.). Vår Fågelvärld, Supplement 9.

Persson, H. 1989. Food selection, movements and energy budgets of staging and wintering geese on South Swedish farmland. Doctoral thesis. Department of Ecology, Animal Ecology, Lund University.

Persson, K.M. 2011. The driving forces behind some lake lowerings in Sweden - examples from Lake Näsbyholmssjön and Lake Hjälmaren. Vatten 67: 101-111. (Swedish with English summary).

Pettersson, E. 2009. Establishment of winter oilseed rape with Biodrill and no-till. Bulletin no. 60 from the Division of Soil Management. Swedish University of Agricultural Sciences, Uppsala. (Swedish).

Phillippona, J. 1985. The Noordoostpolder as a haunt for wintering geese. Limosa 58: 1-6. (Dutch with English summary).

Pihl, S. \& Vikstrøm, T. 2006. Gæs og svaner i mandtal. Fugle og Natur 26(4): 24-25.

Piskunova, V. \& Alsiņa, R. 2010. Possibilities of renewing sugar production in Latvia. Scientific Journal of Riga Technical University 8: 150-156. (Latvian with English summary).

Roomen, M. van \& Madsen, J. (eds.). 1992. Waterfowl and Agriculture: review and future perspective of the crop damage conflict in Europe. Proceedings of the international workshop "Farmers and Waterfowl: Conflict of Coexistence", Lelystad, Netherlands 1991. IWRB Special Publication No. 21, 184 pp. The Ministry of Agriculture, Nature Management and Fisheries, The Netherlands \& The International Waterfowl and Wetlands Research Bureau (IWRB), Slimbridge, Gloucester, UK.

Statens jordbruksverk. 2011. Jordbruket i siffror 1866-2007. Statens jordbruksverk \& Statistiska centralbyrån, Stockholm.

Svenskt vattenarkiv. 1995. Sänkta och torrlagda sjöar. Report. Serie Hydrologi 62, 164 pp. Swedish Meterological and Hydrological Institute, Norrköping.
Söderberg, T. 2006. Miljöeffekter av träda och olika växtföljder - rapport från projektet CAP:s miljöeffekter. Report 2006: 4. Jordbruksverket, Naturvårdsverket \& Riksantikvarieämbetet, Jönköping. (Swedish with English summary).

Weih, M. 2006. Willow short rotation coppice grown on agricultural land - possibilities for improvement of biodiversity and landscape design. Report to Swedish Environmental Protection Agency. Swedish University of Agricultural Sciences, Uppsala. (Swedish with English summary).

Wiman, J. 2012. En studie av nya grödor och deras spridning hos bönder och gods $i$ Skåne, under 1800-talets agrara revolution. Kandidatuppsats. Ekonomisk-historiska institutionen, Lunds Universitet.

\section{Sammanfattning}

Under de senaste decennierna har de flesta gåspopulationer i Sverige och övriga länder i Nordvästeuropa ökat kraftigt i antal. Samtidigt har gässens geografiska utbredning genomgått stora förändringar. Även inom jordbruket har det skett stora förändringar, både vad avser grödor och brukningsmetoder. Av den anledningen fanns det anledning att analysera gässens fältval under hela den period som regelbundna inventeringar genomförts i Sverige. Inte minst eftersom gässens födosök på jordbruksmark sedan lång tid tillbaka orsakat konflikter mellan gäss och jordbrukare. Olika metoder att lindra dessa konflikter har tillämpats, såsom skrämsel, skyddsjakt, viltåkrar, förvaltningsplaner, refugier och ekonomisk kompensation. För att kunna avgöra vilken metod som bör väljas behövs dock aktuella uppgifter om gässens fältval.

Undersökningsområdet utgjordes av sydvästra Skåne, där drygt $60 \%$ av den totala landarealen utnyttjades för jordbruk. De viktigaste grödorna var spannmål, sockerbetor och raps medan potatis framförallt odlades på lätta, sandiga jordar i norra och östra delen av området. Gräsmarker fanns framförallt i östra delen av området samt längs med kusten. Som nattlokal utnyttjade gässen de flesta av områdets sjöar, några åsträckor samt ett flertal kustlokaler.

Insamlandet av fältvalsdata gjordes i samband med mittmånadsinventeringar i oktober, november och januari säsongerna 1977/78-2011/12. I varje flock räknades antalet individ av varje art och ras varefter fälttypen bokfördes så noggrant som möjligt, inte enbart vilken gröda det rörde sig om utan även om fältet skördats, om stubbar harvats, om rapsen var direktsådd, osv.

De besökta gåsfälten har grupperats på följande sex fälttyper: sockerbetor (skördespill samt några 
fall av oskördade betfält), potatis (skördespill), raps (höstsådda fält), spannmålsstubbar (framförallt vete), höstsäd och gräsmarker (inklusive vallar). Födosök på andra fälttyper än dessa sex omnämns i texten, då det totala utnyttjandet av dessa var för lågt för att visas i diagrammen. För att utjämna mellanårsskillnader presenteras resultaten som medelvärden för femårsperioder. Eftersom vi inte fann några skillnader i fältval mellan oktober och november slogs värdena för dessa månader ihop. Som bakgrund till fältvalsuppgifterna redovisas antalet inräknade gäss i form av medelvärden för femårsperioder.

Sädgås var en talrik höstrastfågel i Sydvästskåne då studien inleddes, men området har successivt förlorat i betydelse och numera inräknas få individer $\mathrm{i}$ oktober. Trenden har varit den motsatta $\mathrm{i}$ januari, där antalet numera ligger omkring 16000 individ. En växande andel av sädgässen har om hösten återfunnits på sockerbetsspill och denna fälttyp har under de senaste tio åren även varit väl utnyttjad i januari. Potatis utnyttjades framförallt $i$ januari under perioden 1993-2002. Under de första 15 åren var höstsädesbrodd den helt dominerande fälttypen vintertid och tämligen flitigt utnyttjad på hösten, men uppvisar under de följande 20 åren ett betydligt lägre utnyttjande. Gräsmarker har mest utnyttjats vintertid och då framförallt under åren 1998-2007. Lokalt och tillfälligt, både höst och vinter, har sädgäss ätit morötter, antingen som skördespill eller som lagrade i stuka.

Spetsbergsgås förekom i låga antal under hela undersökningsperioden. Eftersom arten nästan uteslutande uppträdde tillsammans med sädgäss var deras fältval likt den artens.

Bläsgås är en av de arter för vilken såväl antalet rastare som övervintrare ökat markant under undersökningsperioden, även om höstsiffrorna tycks ha planat ut under de senaste 15 åren. På hösten återfanns under de första tio åren en klar majoritet av bläsgässen på antingen höstsäd eller gräsmark. Även under de följande tio höstarna var dessa fälttyper de viktigaste, men därefter har sockerbetsspill varit den dominerande födokällan. Under vintern har höstsäd och gräsmark varit de dominerande fälttyperna under hela undersökningsperioden, även om sockerbetspill fått en ökad betydelse under de senaste tio åren.

Grågås är en annan art för vilken såväl antalet rastare som övervintrare ökat markant under de senaste 35 åren. Under den senaste femårsperioden låg medelvärdena i oktober och januari på drygt 45 000 respektive drygt 15000 individ. Alltsedan de första grågässen sågs på ett sockerbetsfält vid Fo- teviken hösten 1987 har sockerbetsspill varit den helt dominerande födokällan under såväl höst som vinter. Lokalt har grågäss även utnyttjat oskördad spannmål, morotsfält och majsstubbar. I oktober 2006 repade inte mindre än 20000 grågäss oskördad vete i ett översvämmat fält vid Vombsjön.

Även kanadagås har ökat kraftigt $\mathrm{i}$ antal under såväl hösten som vintern och medelantalet $\mathrm{i}$ januari ligger numera på drygt 25 000. Spannmålsstubb var den helt dominerande fälttypen under såväl hösten som vintern de första 15 åren. Sockerbetsspill tog därefter över helt under hösten samt så småningom även under vintern. Till skillnad från övriga arter har även ett relativt stort antal individ utnyttjat raps, framförallt vintertid, under perioden 1993-1997.

Vitkindad gås saknades nästan helt under de första 20 åren. Sedan dess har arten blivit en talrik rastare med drygt 50000 individ i oktober och drygt 30000 i november. Under vintern är arten betydligt fåtaligare. De första tio höstarna återfanns de flesta vitkindade gässen på gräsmark och höstsäd, men sedan kom sockerbetsspill att dominera även denna arts fältval. I januari har de fördelat sig tämligen jämt mellan gräsmark, höstsäd och sockerbetsspill.

Den agrara revolutionen under 1800-talet, med flera nya grödor, samt mekaniseringen efter andra världskriget har markant förändrat det sydvästskånska jordbrukslandskapet. Det tog dock minst två decennier innan en ny gröda eller brukningsmetod blev allmänt accepterad av jordbrukarna, en tidsaspekt att hålla i minnet när gässens svar på desamma diskuteras.

När Gunnar Markgren genomförde sin klassiska studie i slutet av 1950-talet sökte majoriteten av såväl de rastande som övervintrande gässen föda på gräsmark, framförallt på naturliga gräsmarker men även på klövervallar. I vår undersökning däremot var gräsmarkerna av liten betydelse förutom under milda vintrar, då framförallt sädgäss och bläsgäss men även grågäss och vitkindade gäss återfanns på naturliga gräsmarker.

När gässen började söka föda på spannmålsstubb i Sydvästskåne är inte känt. I början av 1800-talet var dock vitkindad gås så nära förknippad med skördade havreåkrar att arten fick namnet $\mathrm{Ha}$ fregås. Med tanke på sitt svenska namn bör även sädgåsen haft en tidig koppling till sädesfält. Eftersom grågås, som är mycket talrik i Sydvästskåne under tidig höst, börjar söka föda på stubbåkrarna så snart fälten har tröskats finns det numera sannolikt endast små mängder spillsäd kvar på dem när det är dags att räkna gässen i mitten av oktober. Däremot kan stubbarna under senhösten ofta erbjuda föda i form av sädesbrodd och ogräs. 
Höstsädens största betydelse för gässen är sannolikt dess tillgänglighet. Närhelst skördespillet är uppätit eller nerplöjt finns det alltid fält med höstsäd för gässen att beta. Och även efter kraftigt snöfall erbjuder fält som vinden blåst rena en rik födokälla.

När potatis och sockerbetor skördades manuellt var dessa grödor ointressanta för gässen. Med introduktionen av maskinell upptagning under 1960-talet fick gässen tillgång till två nya rika födokällor, eftersom speciellt betupptagarna producerade mycket spill. Sädgässen lärde sig snabbt att utnyttja detta, varefter övriga arter successivt följde efter. Sockerbetsspill blev så småningom den viktigaste födokällan under hösten för samtliga här behandlade arter. Att sockerbetsspill blivit en viktig födokälla även i januari under de senaste tio åren beror på att betkampanjen förlängts och numera pågår fram till mitten av januari.

Trots att raps odlats i Sverige sedan 1700-talet utnyttjades den inte som födokälla av gäss under senhöst och vinter före vår studie. Övergången till dubbel-låga, mer välsmakande sorter under 1980-talet ledde inte till någon markant uppgång i utnyttjandet. Raps, särskilt den direktsådda, utnyttjas framförallt när fälten är snötäckta, då denna gröda ofta är den enda som sticker upp genom snön.

Bland nya grödor i Sydvästskåne har majs potential att bli av regional betydelse som gåsföda. Än så länge är det mest sångsvan och grågås som setts söka föda på oskördade och skördade majsfält. Eftersom det finns få odlare av morötter och rödbetor kommer dessa även framöver att vara av betydelse för gäss endast lokalt. Vanligtvis skördas gräsfrö och ärtor för tidigt för att vara tillgängliga för gäss under senhösten, men dessa grödor har blivit flitigt utnyttjade av grågäss under sensommar och tidig höst.

Sydvästskåne tycks uppfylla alla nödvändiga krav för ett område av betydelse för rastande och övervintrande gäss; säkra nattplatser, rik födotillgång, goda siktförhållanden, ostördhet och gynnsamt klimat. Eftersom antalet gäss mångdubblats och samtliga arter numera utnyttjar samma födokällor, ofta i stora blandflockar, uttöms tillgången på föda på varje enskilt fält betydligt snabbare idag än tidigare. Trots det kan gässen oftast finna föda inom fem km från nattplatsen. Vintertid sågs kanadagäss regelbundet söka föda upp till $17 \mathrm{~km}$ och sädgäss upp till $15 \mathrm{~km}$ från sina nattplatser. En faktor som kan reducera fältens tillgänglighet för gässen är de åtgärder som jordbrukarna tar för att hålla dem borta från växande grödor, framförallt höstsäd. Eftersom gåsjakten är av tämligen begrän- sad omfattning och mycket lokal i Sydvästskåne har de flesta gäss förlorat sin tidigare skygghet. Individer av samtliga arter kan idag ses söka föda även i närheten av hus, häckar och skogsbryn, medan de undviker kraftledningar och vindkraftverk.

Genom att jämföra gässens fältval då de hade tillgång till mer än en fälttyp fick vi fram följande preferenslista (högst preferens först): oskördad vete - spillsäd - sockerbetsspill - spillpotatis höstsäd - höstraps. Detta tyder på att gässen under månaderna oktober-januari sällan orsakar några problem för jordbrukarna i denna del av landet. Så länge gässen har tillgång till skördespill visar de nämligen föga intresse för höstsådda grödor. Dessutom tål höstsäd ett högt betestryck utan negativa effekter. Det gäller däremot inte raps, där redan ett svagt betestryck kan förorsaka betydande skördeförluster. Eftersom raps huvudsakligen betas då inga andra fälttyper finns tillgängliga, oftast beroende på att de är täckta av snö, skulle det var en god strategi att koncentrera försöken att skrämma gässen till just de tillfällena.

Ursprungligen utnyttjade varje art sin egen födosöksnisch och de geografiska utbredningarna vintertid var nästan helt utan överlapp. Den stora variationen i födoslag som de flesta gäss utnyttjar i det moderna jordbruket visar på en stor anpassningsförmåga. Under höst och vinter i Sydvästskåne har fem gåsarter förvärvat en mycket bred, men ej identisk födosöksnisch. Inom detta område är kanadagåsen den enda art som söker föda på botten av grunda havsområden, grågåsen den enda art som utnyttjar Scirpus som föda, medan de talrikaste arterna på naturliga gräsmarker i inlandet vintertid var taigasädgås och bläsgås. Synbarligen har de fem arterna vidgat sina födosöksnischer på ett likartat sätt, samtidigt som de behållit sin ursprungliga nisch oinkränkt. Den ursprungliga födosöksnischen kan därmed, förutsatt att den fortfarande existerar, fungera som tillflykt den dag konkurrens utestänger en art från den gemensamma födosöksnischen. Huruvida konkurrens om födan förekommer idag är okänt.

Den pågående klimatförändringen kan öppna möjligheter för gässen att rasta och övervintra närmare sina häckningsområden. Fortsätter trenden från de gångna 35 åren kan detta leda till att de flesta taigasädgäss (skogssädgäss) och kanadagäss kvarstannar och övervintrar norr om Sydvästskåne, medan antalet övervintrande bläsgäss, grågäss och vitkindade gäss ökar. Istället för taigasädgås kommer tundrasädgås, kanske även spetsbergsgås, med stor sannolikhet att etablera sig som övervintrare $i$ denna del av landet. 